Original Research Paper

\title{
Impact of ASA NGO's Microcredit Program on Livelihood of Rural People in Mymensingh District, Bangladesh
}

\author{
${ }^{1}$ Mahbuba Akther Mishu, ${ }^{2}$ Fardous Ara Happy, \\ ${ }^{2}$ Farzana Yeasmin, ${ }^{3}$ G.M. Amzad Hossain and ${ }^{4}$ Md. Hasibur Rahaman Hera \\ ${ }^{I}$ Department of Agricultural Finance, Bangladesh Agricultural University, Mymensingh, Bangladesh \\ ${ }^{2}$ Department of Agricultural Economics, Bangladesh Agricultural University, Mymensingh, Bangladesh \\ ${ }^{3}$ Head Office, Bangladesh Bank, Dhaka, Bangladesh \\ ${ }^{4}$ Plant Pathology Division, Bangladesh Rice Research Institute, Gazipur, Bangladesh
}

\author{
Article history \\ Received: 02-01-2020 \\ Revised: 14-04-2020 \\ Accepted: 12-05-2020 \\ Corresponding Author: \\ Mahbuba Akther Mishu \\ Department of Agricultural \\ Finance, Bangladesh \\ Agricultural University, \\ Mymensingh, Bangladesh \\ Email: misra1402@gmail.com
}

\begin{abstract}
The present study was conducted to see the effect of microcredit provided by the ASA NGO on the rural poor clients in Sadar upazila of Boira Union in Mymensingh district of Bangladesh. The study identified the extent of income generating activities, the adequacy, utilization pattern, repayment performance and cost of credit of the beneficiaries' especially rural poor. A total of 50 rural ASA beneficiaries were collected where 30 from Boira and 20 from Chalk-chatrapur. In the study area, average amount of credit received by the respondents was Tk. 9614.60 and on an average 86.59 percent of the loaned money was utilized for the reported IGAs. Overall loan recovery percentage was found to be quite satisfactory. They repaid their loan on time with the hope of getting more credit in future and because of regular supervision by the association's field level workers and pressure of the group leaders. Six explanatory variables i.e. age, education, family size, occupation, income and expenditure were considered for repayment of loan in empirical model. Age, family size, income and expenditure had significant impact on repayment of loan. Overall income and savings change by taking loan from ASA were 36.04 and 68.69\%, respectively. The findings show that ASA loan brought about positive impact on livelihood improvement of the borrowers. The present study suggests for conducting further study of similar type in other parts of the country to make the findings representative one.
\end{abstract}

Keywords: Microcredit, Rural People, Livelihood and Impact

\section{Introduction}

Bangladesh is one of the most densely populated countries of the world with a population of 158.5 million. Its density of population is 1015 persons per sq. $\mathrm{km}$. which is one of the highest in the world. The current population growth rate is 1.2 percent per annum. At least 45 million people in Bangladesh, almost one third of the total population, live in the rural areas and a significant proportion of them live in extreme poverty. The poverty rate is highest in rural areas, at $36 \%$, compared with $28 \%$ in urban centers and but rural per capita income is much lower than the average national income. Mostly, they are dependent on several sources of micro-credit (MoF, 2014).

Microcredit refers to programs that are poverty focused and that provide financial and business services to the poor people for generation of self-employment and income. Microcredit refers more specifically to making small loans available to poor people, especially those traditionally excluded from financial services, through programs designed specifically to meet their particular needs and circumstances. Most of the terms and conditions are flexible and easy to understand and suited to the local conditions of the community.

The role of microcredit in reducing poverty is now well recognized all over the country. The NGOs are working independently of course, within the legal framework of the GoB with a view to helping the deprived people through facilitating self-employment generation, education, healthcare, nutritional status, family planning, financing and so on. They have been working on community development approaches often 
called target group approach to improve livelihood of those people in the country. For these purposes, they organize the target groups and encourage them to undertake various income generating activities for which they provide necessary training, credit and other support services. A large number of NGOs have been able to reduce poverty of millions of poor households generating self-employment through providing collateral free credit (UNDP, 2014). By accelerating women participation in income generating activities, microcredit has emerged as the most powerful driver of financial inclusion (UNDP, 2014). The NGOs are trying to explore the rural problems and render possible solution through providing collateral free microcredit to them who have least access to credit facilities usually available from banking institutions because of their inability to satisfy the collateral requirement for bank credit (UNFPA, 2014). The rural poor therefore, at present seek financial accommodation to various NGOs available in the countryside. Also, development agencies, banks, universities, consultants, philanthropists and others have increasing to interest in it.

Rural poor in Bangladesh normally do not have access to institutional credit. The nationalized commercial banks do not advance credit for the landless borrowers except for special programs for poverty alleviation. One of the main reasons for low productivity and widespread poverty of our country is the lack of access to productive assets and financial resources by the poor. It is possible to fulfill this need by expanding credit facilities. Credit can provide them with much needed financial assistance. Credit has a vital role in accelerating agricultural production. The vast majority of the farmers in Bangladesh need credit to purchase input like fertilizer, irrigation water, seed, pesticides, labor (hired portion) for the production and even to meet some consumption requirements. The last decade witnessed an explosion in both numbers and the scale of organizations providing microcredit to poor people for escaping from poverty. But lending procedures, target groups and rates of interest are not same among the institutions.

On the other hand, like many other NGOs, Association for Social Advancement (ASA) experience shows that when a rural borrower benefits from a program, her/his entire household benefits and the impact are more sustainable. This knowledge has led ASA to design its programs for the greatest benefit of the rural poor. Now the rural people are actively participating in development activities. They are now more concerned with the concepts of family planning, health sanitation and nutrition and so on. ASA has been motivating rural poor to participate in socio-economic development of the country. ASA provides loan on many income generating activities such as livestock and poultry rearing, vegetable selling, tailoring, petty business, fisheries, beef fattening, rickshaw/van pulling and so on.
Several studies carried out about the impact of microcredit on human livelihood. Islam et al. (2012) conducted study on micro-credit programmes of different NGOs/MFIs: A comparative study. He found that amount of loan taken, experience of poverty alleviation and NGO membership are three important factors of satisfaction level on the micro-credit programme. Another study by Khatun et al. (2012) on impact of micro-credit programmes on poverty alleviation in Bangladesh. This study showed an alternative measurement of poverty change based on the change in household wealth and education of a household. Islam et al. (2014) examine the impact of micro credit to reduce poverty at Trishal Upazila in Mymensingh. The study shows that microcredit disbursed through major NGOs including Grameen Bank, BRAC, ASA plays an important role to reduce poverty by evaluating their socio-economic conditions. Shaha (1997) conducted a study on the production and income between GB member households and non-GB member households in a selected area of Mymensingh district. She observed that annual income as well as expenditure of GB member households was higher than those- of non-GB member households. Sharma and Zeller (1997) studied repayment performance in groupbased credit programs of ASA, BRAC and RDRS in Bangladesh. The study concluded that if the basic principles of prudential banking were adhered to, repayment rates could be good even in poor and remote communities. Khandker (1998) emphasized that microcredit programs were an effective policy instrument for reducing poverty among the poor people with the skills to become self-employed. Zebunnesa (1998) designed a study to look into the impact of selected BRAC activities on women. Karim and Osada (1998) reported the extent of the dropout problem in credit schemes and the impact on micro-credit schemes. Moniruzzaman (1999) conducted an experiment with a number of projects engaged in increasing income and employment opportunities for the rural poor by setting up a separate system of primary co-operatives. Islam (1999) focused the micro credit of SFDP for the rural poor in Sadar Upazila of Bogra district. The researcher studied the impact of SFDP credit operation on income, employment and asset position. Roy (2000) conducted a study on the effectiveness of seasonal crop loan provided by the GB based on selected respondents of Nazirpur Upazila in Pirozpur district. Majority of the selected members productively utilized the loan money in the study villages. Uddin (2001) undertook a study to examine the impact of microfinance programs of Jagorani Chakra and Banchte Shekha on the beneficiaries in some selected areas in Jessore district.

However, minimum condition of living to ensure human dignity that requires housing, clothing, Medicare, sanitation and education. It would be possible to fill up 
the financial needs by extending credit facilities that ultimately would contribute on economic development of the country. Therefore, this study aimed to evaluate the specific objectives:

- To assess the adequacy, utilization and repayment of credit by the respondents

- To investigate into the factors associated with repayment of credit in the study area

- To analyse the impact of ASA's credit program on beneficiaries in the study area

- To identify the problems and constraints of the beneficiaries faced to obtain ASA credit

\section{Methodology}

Keeping in view the objectives of the study and considering the limitation of the research with respect to time, money and other facilities, two villages namely Boira and Chalk-chatrapur under Sadar upazila of Mymensingh district were selected for the study since ASA beneficiaries were mostly situated in the region. A total of 50 rural ASA beneficiaries were collected where 30 from Boira and 20 from Chalk-chatrapur where 7 respondents were engaged in crop farming, 33 were engaged in livestock rearing, 7 were engaged in petty business, 1 was engaged in tailoring and 2 were engaged in van/rickshaw pulling following random sampling techniques with direct interview method on the basis of prominent area of micro-credit during 2013-2014. The selected respondents covered all the professions practiced in the study area with the help of ASA micro credit. Necessary information was also collected from the ASA branch office for the reliability of data.

\section{Analytical Technique}

Tabular analysis was used mostly to classify the collected data and to derive relevant findings. Most tabular analysis was done by using techniques of descriptive analysis such as average, percentage etc. The multinomial regression model was employed to examine the repayment performance of the borrowers in the study area. To calculate the analysis, SPSS software was used and Excel was used to find the result of descriptive analysis for the study.

The specified regression model was as followed:

$$
Y=\beta_{0}+\beta_{1} X_{1}+\beta_{2} X_{2}+\beta_{3} X_{3}+\beta_{4} X_{4}+\beta_{5} X_{5}+E_{i}
$$

Where:

$Y \quad=$ Amount of loan repaid by the loaner in a year (Tk.)

$\beta_{0} \quad=$ Constant term

$X_{1} \quad=$ Age of the respondents (years)

$X_{2} \quad=$ Education (years of schooling)

$$
\begin{array}{ll}
X_{3} & =\text { Family size (No.) } \\
X_{4} & =\text { Income of the household in a year (Tk.) } \\
X_{5} & =\text { Annual expenditure (Tk.) } \\
E_{i} & =\text { Error term }
\end{array}
$$$$
\beta_{0} \text { to } \mathrm{i}_{5}=\text { Coefficient of respective variables. }
$$

\section{Result and Discussion}

\section{Adequacy, Utilization and Repayment of Loan by the Beneficiaries}

Table 1 shows that $86 \%$ of the respondents reported that they got adequate amount of credit from ASA and only $14 \%$ reported that the loan received from ASA was not adequate.

Capital is required for investing in IGAs. To meet this capital requirement credit is helpful as it creates scope for further investment. The overall average amount of credit received by the respondents in the study area was Tk. 9614.6. It is evident that maximum amount of credit was received by the livestock reared group (Tk. 16857) while minimum amount was received by the tailoring category (Tk. 5000) (Table 2).

Respondents had to spend certain amount of money in obtaining credit. Six major components of cost were identified during study (Table 3). Study revealed that overall cost incurred for ASA credit was found to be Tk. 372.33 and average cost for taking risk was found to be Tk. 151 during the period. It was quite clear from the table that respondents having small loan receiver to have incur the lowest cost followed by the respondents of medium and large loan category and total cost decreases if the amount of credit increases.

Study reveals that borrowers on an average received Tk. 9614.60 for investing in different IGAs but they actually utilized on an average Tk. 8607.20 for IGAs and they spent on an average Tk. 207.40 and Tk. 600.00 for household food consumption and household non-food consumption, respectively (Table 4).

Generally, ASA collects credit on installment basis. One loanee has to repay his/her credit in 45 installments. One has to repay a fixed amount of Tk.25 for per thousand tk. plus 15 per cent interest rate charged by ASA. During the week, a field supervisor visits the area. The respondents were not present in the weekly meeting and didn't repay credit installment, although lastly, they were able to repay the due credit money within 45 installments. Table 5 shows the repayment situation of the respondents.

The average amount of loan repaid was found to be Tk. 8050.00 , Tk. 19385.55 , Tk. 11748.40 , Tk. 5750.00 and Tk. 10350.00 for crop farming, livestock rearing, petty business, tailoring and van/rickshaw pulling, respectively. Overall loan recovery percentage observed during the study period was found quite satisfactory. Hope of getting more credit in future had been reported 
by most of the borrowers as the major factor of timely loan repayment. Regular supervision by the bank's field level workers and pressure of group leader and other members of the group also had been reported by some of the borrowers as important factors of timely loan repayment.

Table 1: Adequacy of loan received from ASA in 2014

\begin{tabular}{lc}
\hline Adequacy of loan & Respondents $(\%)$ \\
\hline Yes & 86 \\
No & 14 \\
\hline
\end{tabular}

Source: Field Survey, 2015.

Table 2: Average amount of credit received by the borrowers

\begin{tabular}{lcc}
\hline Loan category & No. of respondents & Average amount (Tk.) \\
\hline Farming & 7 & 7000.00 \\
Livestock rearing & 33 & 16857.00 \\
Petty business & 7 & 10216.00 \\
Tailoring & 1 & 5000.00 \\
Van/rickshaw pulling & 2 & 9000.00 \\
Total & 50 & 9614.60
\end{tabular}

Source: Field Survey, 2015.

Table 3: Amount of cost incurred on the beneficiaries of ASA loan

\begin{tabular}{|c|c|c|c|c|}
\hline \multirow[b]{2}{*}{ Type of cost } & \multicolumn{4}{|c|}{ Loan categories } \\
\hline & A & $\mathrm{B}$ & $\mathrm{C}$ & All \\
\hline Purchase of credit pass book & 10 & 10 & 10 & 10 \\
\hline Revenue stamp for getting loan & 5 & 5 & 5 & 5 \\
\hline Transportation cost & 15 & 20 & 30 & 21 \\
\hline Wage for days lost due to movement to ASA branch & 104 & 114 & 154 & 124 \\
\hline Service charge (Tk. 5 per Tk. 1000) & 50 & 60 & 70 & 60 \\
\hline Photograph & 0 & 0 & 0 & 0 \\
\hline Others $($ Risk $=$ Tk. 10 per Tk. 1000$)$ & 100 & 150 & 205 & 151 \\
\hline Total Cost & 284 & 359 & 474 & 372 \\
\hline
\end{tabular}

Source: Field Survey, 2015.

Note: $\mathrm{A}=$ Cost for obtaining credit for farming, tailoring and rickshaw pulling; $\mathrm{B}=\mathrm{Cost}$ for obtaining credit for livestock and $\mathrm{C}=$ Cost for obtaining credit for petty business.

Table 4: Average amount of loan utilized for different purposes

\begin{tabular}{lllll}
\hline Loan category & $\begin{array}{l}\text { Concerned } \\
\text { ASA (Tk.) }\end{array}$ & $\begin{array}{l}\text { Household food } \\
\text { consumption (Tk.) }\end{array}$ & $\begin{array}{l}\text { Household non-food } \\
\text { consumption (Tk) }\end{array}$ & $\begin{array}{l}\text { All } \\
\text { purpose (Tk.) }\end{array}$ \\
\hline Crop farming & 5000 & 0 & 2000 & 7000 \\
Livestock & 15560 & 1297 & 0 & 16857 \\
Petty business & 9716 & 0 & 500 & 10216 \\
Tailoring & 4260 & 740 & 0 & 5000 \\
Van pulling & 8000 & 0 & 1000 & 9000 \\
All & 8607 & 207 & 600 & 9614 \\
\hline
\end{tabular}

Source: Field Survey, 2015.

Table 5: Amount of principal and interest paid by the beneficiaries

\begin{tabular}{llllll} 
& Average amount paid & & & & \\
Loan category & Installment (No.) & Principal (Tk.) & Interest (TK.) & Total (TK.) & $\begin{array}{l}\text { Percentages of } \\
\text { total repayment }\end{array}$ \\
\hline Crop farming & 45 & 7000 & 1050 & 8050 & 100 \\
Livestock & 45 & 16857 & 2528.55 & 19385.55 & 100 \\
Petty business & 45 & 10216 & 1532.40 & 11748.40 & 100 \\
Tailoring & 45 & 5000 & 750 & 5750 & 100 \\
Van pulling & 45 & 9000 & 1350 & 10350 & 100 \\
Total & 45 & 9614 & 1422.19 & 11036.79 & 100 \\
\hline
\end{tabular}

Source: Field Survey, 2015. 


\section{Factors Analysis}

Regression co-efficient of educational qualification of the respondents was 0.142 being statistically significant. It indicates that repayment of loan is positively and significantly affected by educational qualification of the respondents. The co-efficient of the variable family size was found to be negative $\left(b_{3}=-\right.$ 0.106 ) and statistically insignificant. It indicates that repayment of loan tends to decrease with increase in respondent's family size. Expected association was there with loan repayment behavior. Regression coefficient of the respondents' income was 0.328 which is insignificant. It indicates that keeping other variables constant, 1 unit increase in income would lead to an increase in repayment of loan by 0.328 unit. The coefficient of the variable expenditure of the respondents was also negative (-0.008), which indicates that keeping other variables constant, 1 unit increase in expenditure, would lead to a decrease in repayment performance by 0.008 unit. The value of the coefficient of multiple determinations $\mathrm{R}^{2}$ was 0.696 which means that the explanatory variables included in the model explained $69.6 \%$ of the variation in loan repayment performance of the respondents (Table 6).

\section{Impact of ASA's Credit Program on Beneficiaries}

\section{Impact on Annual Income}

Table 7 shows that before joining to ASA, average annual income was Tk. 48484.71, which increased to Tk. 65958.05 showing $36.04 \%$ income increase in the study area. The change in overall income of the respondent was highest for rickshaw pullers than those of other respondents. It is clear that all the respondents were able to increase their income after being the members of ASA and engaged in IGA.

\section{Impact on Annual Expenditure}

Average change in annual expenditure of the respondents has been shown in Table 8. It can be seen that before joining the ASA income generating loan program the average annual expenditure of the respondents was TK. 43286.12 which was increased to Tk. 57188.40 after joining the ASA. On an average annual expenditure of the respondents increased to Tk. 13902.28 of the area under study.

\section{Impact on Annual Savings}

As evident from Table 9 that the average saving of the respondents was Tk. 5198.59 before joining the ASA and it was increased to Tk. 8769.64 after joining the ASA loan operation. The difference came to Tk. 3571.06 and it constituted about $68.69 \%$ increase in savings of the participating families in the study area. Change in savings between the two groups was mostly in livestock rearing (around three times) compared to other occupations since after taking loan, the beneficiary community received market support from the NGO which ensured their higher market price.

\section{Impact on Food Consumption}

After joining the ASA credit program, the income of the respondents increased consequently, consumption of food has increased. Table 10 shows that overall average increase in consumption of food by the members of the respondent families increased by $54.50 \%$. So, it can be concluded that all the respondents had been able to increase food consumption after becoming the members of ASA.

\section{Impact on Education}

After joining ASA credit program educational status of the respondents' family members had also improved. Table 11 shows that before joining ASA credit program educational status of the respondents family members was 34.20 percent illiterate, 37.92 percent signing ability, 26 percent primary level, 1.86 percent secondary level while after joining ASA credit program, educational status had been improved that means percentage of illiterate members decreased $(18.22 \%)$ and percentage of signing ability, primary level, secondary level, above secondary level increased indicating positive impact of ASA credit program.

Table 6: Estimated co-efficient values

\begin{tabular}{lllll}
\hline Explanatory variables & Co-efficient & t-values & Significant level & SE \\
\hline Constant & 5.09 & 2.53 & 0.01 & 0.10 \\
Age $\left(\mathrm{X}_{1}\right)$ & $0.36^{*}$ & 0.10 & 0.03 & 0.21 \\
Education $\left(\mathrm{X}_{2}\right)$ & $0.14^{* *}$ & 2.23 & 0.58 & 0.06 \\
Family size $\left(\mathrm{X}_{3}\right)$ & -0.10 & -0.55 & 0.25 & 0.29 \\
Income $\left(\mathrm{X}_{4}\right)$ & 0.32 & 1.15 & 0.97 & 0.28 \\
Expenditure $\left(\mathrm{X}_{5}\right)$ & -0.008 & -0.02 & & 0.28 \\
$\mathrm{R}^{2}$ & 0.696 & & & \\
Adjusted $\mathrm{R}^{2}$ & 0.10 & & & \\
F-value & 2.15 & & &
\end{tabular}

Noted: ***significant at $1 \%$ level, $* *$ significant at $5 \%$ level and *significant at $10 \%$ level

Source: Author's estimation based on field survey, 2015. 
Mahbuba Akther Mishu et al. / American Journal of Agricultural and Biological Sciences 2020, Volume 15: 51.59 DOI: 10.3844/ajabssp.2020.51.59

Table 7: Impact on annual income by using of ASA loans (Tk./year)

\begin{tabular}{|c|c|c|c|}
\hline \multirow[b]{2}{*}{ Loan category } & \multicolumn{3}{|c|}{ Annual income } \\
\hline & Before (Tk.) & After (Tk.) & Improvement $(\%)$ \\
\hline Crop Farming & 49000.00 & 61700.00 & 25.92 \\
\hline Livestock rearing & 55476.19 & 74142.86 & 33.65 \\
\hline Petty business & 52947.37 & 71947.37 & 35.88 \\
\hline Tailoring & 42000.00 & 58000.00 & 38.10 \\
\hline Rickshaw pulling & 43000.00 & 64000.00 & 48.84 \\
\hline Average & 48484.71 & 65958.05 & 36.04 \\
\hline
\end{tabular}

Source: Field Survey, 2015.

Table 8: Impact on annual expenditure of the respondents

\begin{tabular}{|c|c|c|c|c|}
\hline \multirow[b]{2}{*}{ Loan category } & \multicolumn{4}{|l|}{ Expenditure } \\
\hline & Before (Tk.) & After (Tk.) & Net change (Tk.) & Percent change $(\%)$ \\
\hline Crop Farming & 40000.00 & 52000.00 & 12000.00 & 30.00 \\
\hline Livestock rearing & 52320.25 & 62570.87 & 16999.88 & 32.49 \\
\hline Petty business & 45560.38 & 62560.26 & 17000.26 & 37.31 \\
\hline Tailoring & 38550.00 & 50250.28 & 11700.28 & 30.35 \\
\hline Rickshaw pulling & 40000.00 & 58560.60 & 18560.60 & 46.60 \\
\hline Average & 43286.126 & 57188.40 & 13902.28 & 32.12 \\
\hline
\end{tabular}

Source: Field Survey, 2015.

Table 9: Impact on annual savings of respondents

\begin{tabular}{|c|c|c|c|c|c|c|c|c|}
\hline \multirow[b]{2}{*}{ Loan category } & \multicolumn{3}{|l|}{ Before } & \multicolumn{3}{|l|}{ After } & \multicolumn{2}{|c|}{ Change in saving } \\
\hline & $\begin{array}{l}\text { Income } \\
\text { (TK.) }\end{array}$ & $\begin{array}{l}\text { Expenditure } \\
\text { (Tk.) }\end{array}$ & $\begin{array}{l}\text { Saving } \\
\text { (Tk.) }\end{array}$ & $\begin{array}{l}\text { Income } \\
\text { (TK.) }\end{array}$ & $\begin{array}{l}\text { Expenditure } \\
\text { (Tk.) }\end{array}$ & $\begin{array}{l}\text { Saving } \\
\text { (Tk.) }\end{array}$ & $\begin{array}{l}\text { Net } \\
\text { change (Tk.) }\end{array}$ & $\begin{array}{l}\text { Percent } \\
\text { change }\end{array}$ \\
\hline Crop Farming & 49000.00 & 40000.00 & 9000.00 & 617003.00 & 52000.00 & 9700.00 & 700.00 & 7.78 \\
\hline Livestock rearing & 55476.19 & 52320.25 & 3155.94 & 74142.86 & 62570.87 & 11571.99 & 8416.05 & 266.67 \\
\hline Petty business & 52947.37 & 45560.38 & 7386.99 & 71947.37 & 62560.26 & 9387.11 & 2000.12 & 27.08 \\
\hline Tailoring & 42000.00 & 38550.00 & 3450.00 & 58000.00 & 50250.28 & 7749.72 & 4299.72 & 124.63 \\
\hline Total & 48484.71 & 43286.12 & 5198.59 & 65958.05 & 57188.40 & 8769.65 & 3571.06 & 68.69 \\
\hline
\end{tabular}

Source: Field Survey, 2015.

Table 10: Impact on food consumption after taking ASA's loan on the basis of loan category

\begin{tabular}{|c|c|c|c|c|}
\hline \multirow[b]{2}{*}{ Loan category } & \multicolumn{4}{|c|}{ Food consumption } \\
\hline & Before (Tk.) & After (Tk.) & Net change (Tk.) & Percent change $(\%)$ \\
\hline Crop Farming & 29470.00 & 42444.00 & 12974.00 & 44.02 \\
\hline Livestock & 30720.00 & 45400.00 & 14680.00 & 47.79 \\
\hline Petty business & 32000.00 & 48000.00 & 16000.00 & 50.00 \\
\hline Tailoring & 22500.00 & 38540.00 & 16040.00 & 71.29 \\
\hline Van pulling & 23750.00 & 39500.00 & 15750.00 & 66.32 \\
\hline Total & 27688.00 & 42776.80 & 15088.80 & 54.50 \\
\hline
\end{tabular}

Source: Field Survey, 2015.

Table 11: Impact on education after taking ASA's loan

\begin{tabular}{lll}
\hline & Before & After \\
Level of education & Family members (\%) & Family members $(\%)$ \\
\hline Illiterate & 34.20 & 18.22 \\
Illiterate & 37.92 & 44.61 \\
Ability to sign & 1.86 & 6.69 \\
Primary level & 1.86 & 6.69 \\
Secondary level & 0 & 0.74 \\
Above secondary level & 100 & 100 \\
Total & 34.20 & 18.22 \\
\hline
\end{tabular}

Source: Field Survey, 2015. 


\section{Impact on Sanitation}

Availability of sanitation facilities is a major concern for reducing rapid spread of communicable disease like diarrhea, typhoid, gastro-intestinal infection etc.

Table 12 shows that the percentage of respondents using sanitary latrine, half sanitary latrine and katcha latrine after involvement in ASA was 3.33, 86.33 and $9.67 \%$ respectively while $71.63 \%$ for katcha latrine of the respondents. So, it can be concluded that after joining the ASA loan operation the respondents became more health conscious.

\section{Impact on Drinking Water}

Table 13 shows that the respondent households used tube-well water of own of their daily work had increased (78.33\%) after their involvement in ASA's credit programe. This indicated the health consciousness of the respondents improved because before joining ASA loan program, only $9.67 \%$ of the women respondents used water from their own tube-well for their daily works.

\section{Beneficiaries Perception on ASA's Income Generating Loan Program}

In this sub-section percentage distribution of the respondents according to their impact of participation perceived in 14 selected change items has been shown in Table 14. Study revealed that there is a notable positive change in decision making, clothing status, children education and relation with husband after taking ASA'S loan. Most of the respondents i.e.64\%, 86.33\%, 92.33\%, $74.33 \%, 100 \%, 100 \%$ and $86.33 \%$ said that there was a positive moderate change in counting ability, access to society, understanding ability, medic are, involvement with social events, dealing with outsides and society's attitude to own respectively but there was mostly unchanged of their own basic education such as reading (72\%) and writing ability (66\%) after taking loan.

Islam et al. (2014) found that the probability of respondents who does not have any change in their poverty situation increases by 15 percent points if the respondents belong to ASA. The probability of respondents who marginally overcame the poverty situation increases if the respondents involved in ASA, BRAC and PROSHIKA (by 2.9, 8.4 and 9.8 percent). have greater influences on poverty alleviation by being members of ASA, BRAC and SSS compared to that of GB.

\section{Problems and Constraints Associated with IGAs Under ASA Loan}

The respondents faced various problems in operating IGAs. Some questions were asked about the problems and constraints faced in micro credit operation of ASA. The identified problems are discussed in Table 15 according to their profession.

Table 12: Impact on sanitation by taking ASA's loan

\begin{tabular}{lll}
\hline Sanitation types & Before $(\%)$ & After $(\%)$ \\
\hline Bushes of open & 0 & 0 \\
Katcha latrine & 71.63 & 9.67 \\
Half sanitary latrine & 28.33 & 86.33 \\
Sanitary latrine & 0 & 3.33 \\
\hline
\end{tabular}

Note: Katcha latrine is a fixed place for human disposal and practiced mainly in the remote area. Source: Field Survey, (2015)

Table 13: Impact on drinking water of taking ASA's loan

\begin{tabular}{lll}
\hline Source of water & Before $(\%)$ & After $(\%)$ \\
\hline Water from river/pond & 6.33 & 0 \\
Tube-well of other & 74.00 & 21.67 \\
Tube-well of own & 9.67 & 78.33 \\
\hline Sour
\end{tabular}

Source: Field Survey, 2015

Table 14: Impact of ASA's income generating loan program on respondent's perception

\begin{tabular}{|c|c|c|c|c|}
\hline \multirow[b]{2}{*}{ Perceptions } & \multicolumn{4}{|c|}{ Extent of changes*(in percentage) } \\
\hline & 4 & 3 & 2 & 1 \\
\hline Increased reading ability & 4.00 & 24.00 & 72.00 & 0.00 \\
\hline Increased writing ability & 4.00 & 30.00 & 66.00 & 0.00 \\
\hline Increased participation in family decision making & 88.00 & 12.00 & 0.00 & 0.00 \\
\hline Improvement in clothing status & 66.00 & 26.33 & 7.67 & 0.00 \\
\hline Increased counting ability & 36.00 & 64.00 & 0.00 & 0.00 \\
\hline Increased access to society & 13.67 & 86.33 & 0.00 & 0.00 \\
\hline Improved understanding ability & 7.67 & 92.33 & 0.00 & 0.00 \\
\hline Improved medicare & 18.00 & 74.33 & 7.67 & 0.00 \\
\hline Increased involvement with social events & 0.00 & 100.00 & 0.00 & 0.00 \\
\hline Improvement in dealing with outsides & 00.00 & 100.00 & 0.00 & 0.00 \\
\hline Improvement in society's attitude to own & 00.00 & 86.33 & 13.67 & 0.00 \\
\hline Improved relation with husband & 92.33 & 0.00 & 1.67 & 6.00 \\
\hline Improved relation with in-laws & 00.00 & 50.00 & 50.00 & 0.00 \\
\hline Improved in children education & 63.67 & 36.33 & 0.00 & 0.00 \\
\hline
\end{tabular}

Note: Extent of changes* ( 4 = Notable increase, 3 = Moderate increase, $2=$ Unchanged and $1=$ Decreased) Source: Field Survey, 2015 
Table 15: Problems and constraints associated with IGAs under ASA loan

\begin{tabular}{lllllll}
\hline Problems and constraints & $\begin{array}{l}\text { Crop } \\
\text { farming }(\%)\end{array}$ & $\begin{array}{l}\text { Livestock } \\
\text { rearing }(\%)\end{array}$ & $\begin{array}{l}\text { Petty } \\
\text { business }(\%)\end{array}$ & $\begin{array}{l}\text { Tailoring } \\
(\%)\end{array}$ & $\begin{array}{l}\text { Rickshaw } \\
\text { pulling }(\%)\end{array}$ & $\begin{array}{l}\text { Average } \\
\text { percentage }\end{array}$ \\
\hline Early starting of repayment period & 100 & 81.81 & 71.43 & 100 & 100 & 90.65 \\
High rate of interest & 85.72 & 84.85 & 85.72 & 100 & 50 & 81.26 \\
Unavailability of credit & 57.14 & 54.54 & 85.72 & 70.50 & 50 & 63.58 \\
Credit inadequate & 42.86 & 33.67 & 28.57 & 27.94 & 19.34 & 30.48 \\
Religious prejudice & 57.14 & 0 & 42.85 & & 0 & 19.99 \\
Lack of facilities (Market and storage) & 85.71 & 30.30 & 0 & 0 & 0 & 23.20 \\
\hline
\end{tabular}

Source: Field Survey, 2015

High rate of interest is one of the problems of taking loan from ASA as well as other NGOs. In the study area on an average majority $(90.65 \%)$ of the respondents expressed it as a major problem of taking loan from ASA. They $(63.58 \%)$ did not get credit in time for their IGAs. About 90.65 percent of the total respondents complained that starting of repayment period was early for them because it was very difficult to get return from any sector so quickly. The amount of credit provided by ASA was not sufficient to operate IGAs properly was said by few respondents. In the study area, there was few religious prejudice (19.99\%) and other facility (23.20\%) to conduct any kind of business with the help of the ASA micro credit.

Islam et al. (2012) found that ASA NGO participants knew actual interest rate more compared to other NGOs in Bangladesh. The NGO scored highest compared to others micro credit institutions i.e., BRAC, GB, PROSHIKA, TMSS, SSS in terms of poverty reduction of its loan beneficiaries. Another study of Islam et al. (2014) in his study found that major NGOs including Grameen Bank, BRAC, ASA plays an important role to reduce poverty by generating employment, improving level of living by better education, better health facilities and higher health expenditure. Interest on credit products (\%) in flat rate was $14.4 \%$ in the year. The study of Chowdhury et al. (2005) recommends that the impact of micro-credit on poverty alleviation is particularly strong for about six years with some leveling off after that point.

\section{Conclusion, Policy Recommendation and Future Research}

Micro-credit was conceived as a means of enabling the poor to have easy access to small amounts of credit for undertaking economic activities with no collateral requirement. In the study, average annual income of ASA members was higher for all kinds of occupation i.e., farmers, livestock rarer, petty businessmen, tailors, van/rickshaw pullers including increase in annual saving of the members. In case of farming the saving was the highest of all loan categories. Borrowers on an average utilized almost total amount of their received micro credit loan from the NGO through investing in different IGAs. In the study area the overall repayment rate was quite satisfactory. Hope of getting more credit in future, regular supervision by the bank's field level workers and pressure of group leader had been reported by most of the borrowers as the major factors of timely loan repayment. It can be concluded that ASA income generating loan program brought positive impact on income, saving, food consumption, land ownership, education and sanitation of the respondents. The problems faced by the respondents were early repayment, high rate of interest, unavailability of credit in time, insufficient amount of credit, religious prejudice, lack of marketing and storage facilities etc. Government and different policy making institutions should analyze the livelihood and poverty alleviation parameters of other NGOs of the country like ASA and come forward to minimize the barriers of the beneficiaries to the way of utilizing their loan for IGAs. Further research can be conducted on the specific parameters of the livelihood improvement with comparison with other non.

\section{Acknowledgment}

The authors express their earnest gratitude to the respondents and stakeholders of the study areas for their alliance and assistance in conducting surveys and collecting the data and information.

\section{Author's Contributions}

Mahbuba Akther Mishu: Designed, collected and checked the analyzed data; prepared the draft manuscript and approved the final manuscript.

Fardous Ara Happy: Coordinated the study, analyzed the data and supervised the draft manuscript.

Farzana Yeasmin: Contributed in model specification and data interpretation, and reviewed the draft manuscript.

G.M. Amzad Hossain: Coordinate in field survey, data cleaning and manuscript preparation.

Md. Hasibur Rahaman Hera: Coordinate for connecting with stakeholder, analyzing the data and preparing manuscripts. 


\section{Ethics}

This article is original and contains unpublished material. The corresponding author confirms that all of the other authors have read and approved the manuscript and no ethical issues involved.

\section{References}

Chowdhury, M.J.A., D. Ghosh and R.E. Wring, 2005. The impact of micro-credit on poverty: Evidence from Bangladesh. Progress Dev. Stud., 5: 298-309.

Islam, M., M.A. Khatun, D. Hossain and J. Alom, 2012. Micro-credit programmes of different NGOs/MFIs: A comparative study. J. Bangladesh Agric. Univ., 10: 297-302.

Islam, M.N., M.T. Hossain and S. Afrin, 2014. Impact of micro-credit to reduce poverty: A case study of Mymensingh. University of Mymensingh.

Islam, S., 1999. Micro-credit for the Poor: A Study of Small Farmers Development Project (SFDP) in Sadar Thana of Bogra District. MS Thesis, Bangladesh Agricultural University, Mymensingh.

Karim, M.R. and M. Osada, 1998. Dropping out an emerging factor in the success of micro credit based poverty alleviation programmes. University of Rajshahi.

Khandker, S.R., 1998. Fighting poverty with microcredit Experience in Bangladesh. The University Press Limited, Red Crescent Building, Dhaka, Bangladesh.

Khatun, M.A., M.A. Islam and S. Majumder, 2012. Impact of micro-credit programmes on poverty alleviation in Bangladesh. Bangladesh J. Agric. Econom., 35: 115-130.

MoF, 2014. Bangladesh economic review, finance division. Ministry of Finance, Government of the People's Republic of Bangladesh, Dhaka, Bangladesh.
Moniruzzaman, M., 1999. Performance of selected Bangladesh Rural Development Board (BRDB) women co-operatives and Grameen Bank (GB) groups, A Comperation and Analysis. MS Thesis, Bangladesh Agricultural University, Mymensingh.

Roy, A.K., 2000. Effectiveness of seasonal crop loan provided by the Grameen Bank in a selected area of pirojpur district. MS Thesis, Bangladesh Agricultural University, Mymensingh.

Shaha, S.S., 1997. Production and income between Grameen Bank-member households and NonGrameen Bank member households: A comparative study in Mymensingh District. MS Thesis, Bangladesh Agricultural University, Mymensingh.

Sharma, M. and M. Zeller, 1997. Repayment performance in group-based credit programs in Bangladesh: An empirical analysis. World Dev., 25: 1731-1742.

DOI: $10.1016 / \mathrm{S} 0305-750 \mathrm{X}(97) 00063-6$

Uddin, G.M.K., 2001. A comparative economic analysis on micro finance programme of Jagorani Chakra and Banchte Shekha in some selected areas of Jessore District. MS Thesis, Bangladesh Agricultural University, Mymensingh.

UNDP, 2014. UNDP microfinance and financial services projects.

UNFPA, 2014. State of world population. UNFPA, New York.

Zebunnesa, M.R., 1998. Impact of selected rural development programme of BRAC on household income generation through increased women participation in a selected area of Mymensingh District. MS Thesis, Bangladesh Agricultural University, Mymensingh. 